of Sulphur Metabolism, pp. 123-140) (Churchill-Livingstone, Edinburgh, 1971).

20. Schulman, J. D. (ed.): Cystinosis (No. (NIH) 72-249, United States Depart ment of Health, Education, and Welfare, Public Health Service, National Institutes of Health. Washington, D.C., 1972)

21. Schulman, J. D., Wong, V. G.. Kuwubara, T., Bradley, K. H., and Seegmiller, J. E.: Intracellular cystine content of leukocyte populations in cystinosis. Arch. Intern. Med., 125: 660 (1970).

22. Scriver, C. R., Davies, E., and Lamm, P.: Accelerated selective short column chromatography of neutral and acidic amino acids on a Beckman-Spinco Analyzer, modified for simultancous analysis of two samples. Clin. Biochem., I: 179 (1968)

23. Seegmiller, J. E., Friedman, T.. Harrison, H. E., Wong, V.. and Schneider, J A.: Cystinosis: Combined clinical staff conference at the National Institutes of Health. Ann. Intern. Med., 68: 883 (1968)

24. Spackman. D. H.. Stein. W. H., and Moore, S.: Automatic recording apparatus for use in the chromatography of amino acids. Anal. Chem., 30:1190 (1958).

25. We are grateful to Professor H. Taylor. University of Otago, Dunedin, New Zealand, for suggesting the chemical method for DTT measurement. Details of these studies are available elsewhere (6).

26. Presented in part at the Annual Meeting of the Canadian Society for Clinical Investigations, Winnipeg, January 1975 (Goldman, H., DePape-Brigger. D. Delvin, E., and Scriver, C.: Clin. Res. 22: 740A (1974)).

27. Consent for this project was obtained under informed conditions and the protocol was reviewed by the Standing Committee on Ethics of the Montreal Children's Hospital.

28. This work was supported by grants from the Medical Research Council (Studentship to D. DePage-Brigger), the Quebec Network of Genetic Medicine, and the McGill University-Montreal Children's Hospital Research Institute.

29. The source material for this manuscript was submitted in partial fulfillment of the requirements for a Master's thesis in the Department of Biology, McGill University.

30. Requests for reprints should be addressed to: C. R. Scriver, M.D., The DeBelle Laboratory for Biochemical Genetics, Medical Research Council Group in Genetics. McGill University-Montreal Children's Hospital, Research Institute, 2300 Tupper St., Montreal, Quebec H3H 1 P3 (Canada).

31. Received for publication May 11, 1976

32. Accepted for publication July 29,1976
Calcium ionophore ciliary dyskinesia factor cystic fibrosis

rabbit tracheal bioassay

\title{
The Biologic Activities of Cystic Fibrosis Serum. I. The Effects of Cystic Fibrosis Sera and Calcium Ionophore A 23187 on Rabbit Tracheal Explants
}

\author{
BRUCE IAN BOGART \\ Department of C'ell Biology', New' York University' Medical Center, New York, New' York, USA
}

ELAINE J, CONOD, AND JAMES H. CONOVER ${ }^{(25)}$

Department of Pediatrics, Albert Einstein College of Medicine, Bronx, New' York, USA

\begin{abstract}
Summary
An ionophore A23187-induced increase in membrane permeability to calcium ions in culture medium produced a rabbit tracheal mucociliary response indistinguishable from that caused by cystic fibrosis (CF) sera on three different occasions. Specific chelation of calcium jons with EGTA in the basal medium Eagle (BME) media with no additive or in native CF sera abolished the mucociliary disturbances in all cases. Increased membrane permeability to calcium may be important in the production of the mucociliary response by $\mathrm{CF}$ serum factor(s) in the tracheal assay system.
\end{abstract}

\section{Speculation}

CF serum factor(s) may be acting on the cultured rabbit tracheal explant cellular membranes to produce altered permeability to ions. This alteration in membrane permeability may be promoting a loss of intracellular communication and cellular injury. Such changes on the celluiar level may be related to the pathophysiology of this genetic disorder.

Cystic fibrosis is an autosomal recessive disease that is characterized by the dysfunction of many exocrine glands $(6,11)$ Although elevated sodium chloride in the sweat of CF subjects remains the most reliable parameter of the disease (5), the existence of a serum factor(s) in affected and carrier subjects. capable of producing in vitro mucociliary disturbances $(4,19)$, seems relevant to some aspects of the pathophysiology of the disease. Whole sera from CF and obligate heterozygous subjects have been described as promoting the so-called ciliary dyskinesia response when exposed to pieces of cultured rabbit tracheal ciliated epithelium $(4,19)$. In addition, sweat and saliva from $\mathrm{CF}$-affected individuals promotes an alteration in the ionic content of salivary secretions upon retrograde perfusion $(12-14)$.

The biologic mechanisms through which CF homozygote and heterozygote sera mediate the observed alterations in the tracheal epithelial bioassay system are not understood. However, the biologic basis in ciliary disturbances and secretory processes have been linked to elevated intracelluar calcium levels in several other experimental systems involving mollusks (17) and mammalian mast cells $(3,10)$. In these systems, an experimentally induced increase in membrane permeability to calcium ions by jonophore A 23187 resulted in functional alterations in ciliary movememt and secretory processes. Ionophore A23187 selectively increases membrane permeability to calcium ions $(15.16$. 21).

In an effort to determine whether increased permeability to calcium ions could explain the CF serum response in the tracheal bioassay system, we selectively increased the membrane perme- 
ability of the tracheal epithelium to calcium ions by the addition of calcium ionophore A23187 to the bioassay system in combination with various test solutions. There studies are of particular interest since the CF serum ciliary dyskinesia factor (CDF) promotes both a ciliary and a secretory response in these same tracheal explants. In addition, we chelated calcium in sera and test solutions to study the effect of a reduction of calcium on the tracheal explant bioassay.

\section{MATERIALS AND METHODS}

\section{TEST SAMPLES}

Venous blood was drawn from CF-affected individuals and control subjects. Medical histories excluded autoimmune and pulmonary diseases. These samples were obtained through the Cystic Fibrosis Outpatient Clinic of the Department of Pediatrics, Columbia College of Physicians and Surgeons, New York, New York. The blood was allowed to clot at $4^{\circ}$ and, after clot retraction, was spun at $850 \times g$ for $10 \mathrm{~min}$. The serum was collected and stored at $-70^{\circ}$ until use. The status of each donor serum was confirmed by bioassay, in a manner previously described (4).

Basal medium Eagle (Gibco), without serum and containing $1.8 \mathrm{mM} \mathrm{CaCl}$, was tested alone, with $2.5 \mathrm{mM}$ ethyleneglycolbis- $\beta$-aminoethyl ether- $N, N$-tetraacetic acid (EGTA), with ionophore or with the latter two in combination. Varying concentrations of calcium $(2.75 \mathrm{mM}, 4.0 \mathrm{mM}$, and $5.40 \mathrm{mM}$ ) were obtained for testing by the addition of anhydrous calcium chloride to the BME. These various concentrations were also tested in the bioassay alone or with the addition of either $10 \mu \mathrm{l}$ or $20 \mu \mathrm{l}$ of calcium ionophore $(10 \mathrm{mg} / \mathrm{ml})$.

Ionophore A 23187 (lot 361-V02-252-1) was kindly supplied by the Eli Lilly Company. This antibiotic is produced by fermentation of Streptomyces chartreusis NRRL 3882 and has a molecular weight of 523 . A stock solution containing $10 \mathrm{mg}$ ionophore $/ \mathrm{ml}$ of absolute ethanol was prepared and kept frozen in the dark until use. 10 $\mu \mathrm{l}$ and $20 \mu \mathrm{l}$ aliquots of this stock were added either to $1 \mathrm{ml}$ serum of $1 \mathrm{ml}$ BME for assay in the rabbit tracheal system. As a control, absolute ethanol (E.tOH), was also tested in the bioassay system after mixing $1 \% \mathrm{EtOH}(\mathrm{v} / \mathrm{v})$ with BME or serum.

EGTA (Sigma), $2.5 \mathrm{mM}$ in $0.9 \%$ sodium chloride, was used as a chelator of calcium in this study, both in BMF: and serum and in the presence and absence of the ionophore. All test solutions containing EGTA were incubated at room temperature for $15 \mathrm{~min}$ before bioassay were performed to allow for calcium chelation.
Each experimental sample, whether serum of BME plus additives, was tested three to six separate times using explants from different rabbits. The serum was obtained from three $C F$ and two control individuals.

\section{CULTURE OF TRACHEAL TISSUE AND BIOASSAY}

Normal, male, white New Zealand rabbits, 6-7 pounds in weight, were used. The trachea were removed and prepared for short term culture as previously described (4). After 2-3 days of culture at $37^{\circ}$, the tissue explants were examined and the bioassay performed. Explants were examined in the culture flasks by light microscopy $(100 \times)$ using an inverted Unitron microscope. Pieces with synchronous, actively beating cilia, minimal outgrowth, and freedom from contamination with mucus or hemoglobin were selected and circled for exposure to the test sample.

Those pieces selected were removed from the flasks and transferred to a glass slide upon which 2 drops of the test sample had been placed. A coverslip was then placed on the slide over the explant and the sample. The assay was monitored at $37^{\circ}$ through an inverted microscope with a $40 \times$ water immersion objective. An appropriate border of cilia of each specimen was visualized within 15-30 sec after the tissue was exposed to the sample. The ciliary action was observed during the succeeding $3 \mathrm{~min}$. The result was recorded and the observation continued for an additional $3 \mathrm{~min}$. For the purposes of these experiments, this usual bioassay period was extended to $9 \mathrm{~min}$.

In addition to ciliary dyskinesia, an obvious component of a positive response for which the serum substance in CF is named, two other parameters of the response were observed and recorded at the various time intervals. These parameters included mucous secretion and the occasional appearance of free-floating cells along the microscopically observed brush border. The times of their appearance were scored separately and did not necessarily correspond with either the ciliary aspect observed or with each other. However, ciliary dyskinesia never occurred without the appearance of mucous secretion during the bioassay interval. It was not possible to determine which of these two facets of the CDF response preceded the other. The occasional appearance of free-floating cells in the bioassay was always preceded by ciliary dyskinesia and mucus secretion. The frequency of this event was not high enough during the assay interval to permit meaningful interpretation in this study and therefore was not included in these scored results.

Each test sample was alternately blind to one of two observers and performed on at least three separate occasions. Gradation of ciliary reaction and mucus production were generally not considered of importance. However, subjectively a ". " designation was used to indicate no change in the tissue, a " \pm " designation

Table 1. C $a^{++}$-ionophore promotion of mucociliary disturbances in cultured rabbit tracheal epithelium'

\begin{tabular}{|c|c|c|c|c|c|c|}
\hline \multirow{3}{*}{ Test sample } & \multicolumn{6}{|c|}{ Mucociliary disturbance } \\
\hline & \multicolumn{3}{|c|}{ Ciliary dyskinesia } & \multicolumn{3}{|c|}{ Mucus secretion } \\
\hline & $3 \mathrm{~min}$ & $6 \mathrm{~min}$ & $9 \min$ & $3 \mathrm{~min}$ & $6 \mathrm{~min}$ & $9 \mathrm{~min}$ \\
\hline BME $(1.8 \mathrm{mM} \mathrm{(aCl})$ & - & - & - & - & - & - \\
\hline $\mathrm{BME}+2.5 \mathrm{mM}$ EGTA & - & - & - & - & - & - \\
\hline BME $(1 \mathrm{ml})+10 \mu \mathrm{l}$ ionophore $\left(2 \times 10^{3} \mathrm{M}\right)$ & - & - & - & - & - & - \\
\hline BME $(1 \mathrm{ml})+10 \mu \mathrm{EtOH}$ & - & - & - & - & - & - \\
\hline BME $+2.5 \mathrm{mM}$ EGTA $(1 \mathrm{ml})+10 \mu l$ ionophore & - & - & - & - & - & - \\
\hline BME $\left(5.4 \mathrm{mM}^{(} \mathrm{aCl}_{2}\right)$ & - & - & - & - & - & - \\
\hline $\mathrm{BME}+2.5 \mathrm{mM}$ EGTA & - & - & - & - & - & - \\
\hline BME $(1 \mathrm{ml})+10 \mu \mathrm{l}$ ionophore $\left(2 \times 10^{3} \mathrm{M}\right)$ & \pm & + & ++ & - & + & $+t$ \\
\hline BME $(1 \mathrm{ml})+10 \mu \mathrm{EtOH}$ & - & - & - & - & - & - \\
\hline $\begin{array}{l}\text { BME }+2.5 \mathrm{mM} \text { EGTA }(1 \mathrm{ml})+10 \mu \mathrm{l} \text { ionophore }(2 \times \\
10: \mathrm{M})\end{array}$ & - & - & - & - & - & - \\
\hline
\end{tabular}

'BME: basal medium Eagle; - : no ciliary dyskinesia, no mucus production; \pm : slight dyskinesia, slight mucus production; + : strong dyskinesia, copious mucus production; $++:$ very marked asynchrony in ciliary beat, near obliteration of field by mucus production. 
Table 2. Calcium requirements for C $^{++}{ }^{+-}$-ionophore $A 23187$ response in tracheal epithelia'

\begin{tabular}{|c|c|c|c|c|c|c|}
\hline \multirow{3}{*}{ Test sample } & \multicolumn{6}{|c|}{ Mucociliary disturbance } \\
\hline & \multicolumn{3}{|c|}{ Ciliary dyskinesia } & \multicolumn{3}{|c|}{ Mucus secretion } \\
\hline & $3 \mathrm{~min}$ & $6 \mathrm{~min}$ & $9 \mathrm{~min}$ & $3 \mathrm{~min}$ & $6 \mathrm{~min}$ & $9 \mathrm{~min}$ \\
\hline $1 \mathrm{mlBME}\left(2.75 \mathrm{mM} \mathrm{CaCl}_{2}\right) 10 \mu \mathrm{l}$ ionophore $\left(2 \times 10^{-3} \mathrm{M}\right)$ & - & \pm & + & - & - & \pm \\
\hline $1 \mathrm{ml} \mathrm{BME}(4.08 \mathrm{mM} \mathrm{CaCl}) 10 \mu$ lionophore $\left(2 \times 10^{3} \mathrm{M}\right)$ & - & + & ++ & - & \pm & + \\
\hline $\left.1 \mathrm{ml} \mathrm{BME}(5.40 \mathrm{mM} \mathrm{CaCl})_{2}\right) 10 \mu \mathrm{l}$ ionophore $\left(2 \times 10^{-3} \mathrm{M}\right)$ & \pm & + & ++ & - & + & ++ \\
\hline $\begin{array}{l}1 \mathrm{ml} \mathrm{BME}(2.75 \mathrm{mM} \mathrm{CaCl}) 20 \mu \mathrm{l} \text { ionophore }\left(4 \times 10^{-3}\right. \\
\mathrm{M})^{2}\end{array}$ & - & + & ++ & - & + & ++ \\
\hline
\end{tabular}

1 BME: basal medium Eagle.

${ }^{2}$ Note that this sample represents a doubling of the ionophore concentration.

Table 3. Effect of $\mathrm{Ca}^{++}$-ionophore in human sera on rabbit tracheal explants ${ }^{1}$

\begin{tabular}{|c|c|c|c|c|c|c|}
\hline \multirow{3}{*}{ Donor } & \multicolumn{6}{|c|}{ Mucociliary disturbance } \\
\hline & \multicolumn{3}{|c|}{ Ciliary dyskinesia } & \multicolumn{3}{|c|}{ Mucus secretion } \\
\hline & $3 \mathrm{~min}$ & $6 \mathrm{~min}$ & $9 \mathrm{~min}$ & $3 \mathrm{~min}$ & $6 \mathrm{~min}$ & $9 \mathrm{~min}$ \\
\hline NS & - & - & - & - & - & - \\
\hline NS $+10 \mu \mathrm{l}$ ionophore $\left(2 \times 10^{3} \mathrm{M}\right)$ & - & + & + & - & \pm & \pm \\
\hline $\mathrm{NS}+10 \mu \mathrm{EtOH}$ & - & - & - & - & - & - \\
\hline CFS & \pm & + & ++ & \pm & + & ++ \\
\hline $\mathrm{CFS}+2.5 \mathrm{mM}$ EGTA & - & - & N.T. & - & - & N.T. \\
\hline CFS + vehicle control & - & + & + & - & + & + \\
\hline
\end{tabular}

'NS: normal serum; CFS: cystic fibrosis serum; vehicle control $=0.9 \% \mathrm{NaCl}, \mathrm{pH} 7.8$, used to solubilize EGTA; N.T.: not tested.

for slight dyskinesia or slight mucus production, " + " for strong dyskinesia or copious mucus production, and " ++ " for very marked asynchrony in the ciliary beat or near obliteration of the microscopic field with mucus. Reproducibility of the test designations was $80-100 \%$.

With each bioassay, a negative control serum was tested to initially evaluate the vitality of the tissue. If no dyskinesia or mucus production was observed with the control serum, bioassays of test samples were performed and the results judged reliable.

\section{RESULTS}

BME culture medium with $1.8 \mathrm{mM}$ calcium did not produce any visible mucociliary disturbances in the rabbit tracheal epithelium when bioassayed alone, as seen in Table 1 . The addition of ethanol or EGTA to this BME with $1.8 \mathrm{mM}$ calcium did not promote any change in the explanted tracheal epithelium. Similarly, the Ca-ionophore-supplemented BME at this level of calcium did not elicit the mucociliary disturbance responses in the tracheal tissue. In contrast, when BME was supplemented to a level of $5.4 \mathrm{mM}$ calcium chloride, ionophore A23187 generated a CF-like response. This response was indistinguishable from that produced by CF sera, and was eliminated by the addition of EGTA to the medium-ionophore mixture (Table 1).

Calcium levels as low as $2.75 \mathrm{mM}$, with a constant dose of $2 \times$ $10^{-3} \mathrm{M}$ Ca-ionophore were capable of promoting a CF-like CDF response in the bioassay (Table 2 ). The component ciliary dyskinesia and mucus secretion vectors of the CDF response were seen to be intensified as the calcium level of the test solution was increased and to be directly related to the calcium concentration of the BME (Table 2). The strengthening of the mucociliary disturbances was also observed when the calcium level was kept constant $(2.75 \mathrm{mM})$ and the ionophore concentration increased to $4 \times 10^{-3} \mathrm{M}$, as seen in Table 2 .

It can be seen in Table 3 that addition of the calcium ionophore to a normal control sera that had previously tested negatively for the CDF response resulted in a sera that now promoted a CF-like CDF response in the bioassay. In addition, EGTA supplemented to CF sera that formerly promoted mucociliary disturbances was observed to abolish the mucociliary disturbances activity of the CF sera.

\section{DISCUSSION}

We have observed that a direct relationship exists between the development of the CF-like mucociliary disturbances and the concentration of both calcium and calcium ionophore A23187 in the rabbit trachea bioassay system. Addition of ionophore A23187 to BME with the calcium concentration $(1.8 \mathrm{mM})$ below normal physiologic concentrations $(2.25-2.75 \mathrm{mM})$ did not produce mucociliary disturbances. Elevations of calcium concentrations in BME from $2.7 \mathrm{mM}$ to $4.08 \mathrm{mM}$ and subsequently to $5.40 \mathrm{mM}$, in the presence of fixed ionophore concentration, resulted in an acceleration of the mucociliary disturbances that was manifested by a reduction in the time necessary for ciliary dyskinesia to be observed and concurrent increase in mucus secretion. It appears that a minimum calcium concentration similar to that of normal sera is required as a cofactor in the production of mucociliary disturbances by ionophore A23187. Similar results were observed when the calcium concentration was kept constant $(2.75 \mathrm{mM})$ and the calcium ionophore dose was doubled to $4 \times 10^{-3} \mathrm{M}$. Addition of the calcium ionophore A 23187 to normal sera resulted in an epithelial response indistinguishable from that seen when CF sera exposed to the bioassay tissue. Subsequently, EGTA supplemented to either ionophore plus BME or CF sera effectively eliminated and mucociliary disturbances in the rabbit trachea bioassay.

Calcium ionophore $\mathrm{A} 23187$ has been shown to induce a secretory response in several glands $(3,7,8,10,20)$, potassium release by the parotid gland slices (18), and ciliary arrest in mussel gills (17). These effects are believed to be related to an influx of calcium ions from the extracellular medium which is mediated by an increase in membrane permeability induced by the ionophore $(15,16,21)$. The possibility that ion disturbances are an important factor in cystic fibrosis can be exemplified by the altered ion concentrations in the sweat of CF subjects (5); 
the altered sodium readsorption by rat salivary ducts upon perfusion with sweat and saliva from CF subjects (12-14); and the altered calcium levels found in saliva from $C F$ patients $(1,2,9$. 22). Our demonstration that the mucociliary disturbances produced by $C F$ sera can be inhibited by addition of the calcium chelator, EGTA, indicates that calcium may be an important cofactor in the production of the mucociliary response by $(F$ serum factor(s). In addition, the observation that the mucociliary response can be mimicked by the calcium ionophore indicates that increased membrane permeability to extracellular calcium is necessary for the response to occur.

These considerations support the view that a possible increased membrane permeability to calcium may be important in the production of the mucociliary response produced by $\mathrm{CF}$ serum factor(s) in the tracheal assay system. Furthermore, the CF serum factor(s) may be acting on cell membranes to produce altered membrane permeability that may be related to the pathophysiology of the disease.

\section{CONCLUSION}

Calcium ionophore A23187 produces a CF-like mucociliary disturbance in rabbit tracheal explants when added to BME. The CDF-like response was directly related to the concentration of calcium or ionophore A 23187 in the test solution. Calcium chelation with EGTA abolished the ionophore-induced response in BME. Calcium ionophore A23187 also induced the CDF response upon addition to control sera that had previously given a negative test, whereas, EGTA eliminated the mucociliary disturbance upon addition to CF sera. These results indicate that calcium is an important cofactor in the production of the $\mathrm{CF}$ sera-induced mucociliary disturbances in the tracheal explant bioassay system and that altered membrane permeability to calcium can also produce a CDF-like response to BME. CF serum (factor(s) may be acting at the level of the cell membrane to produce an altered membrane permeability that may be related to the cytopathology of this disease.

\section{REFERENCES AND NOTES}

1. Bloomficld, J., Warton, K. L., and Brown, J. M.: Flow rate and inorganic components of submandibular salivat in cystic fibrosis. Arch. Dist. Childhood, 48: 267 (1973).

2. Chernick, W. S.. Barbero, G. J., and Perkins, F. S.: Studies on submaxillary saliva in cystic fibrosis. J. Pediat.. 59: 890 (1961).

3. Chochrane, D. E.. and Douglas, W. W.: Calcium-induced extrusion of secretory granules (exocytosis) in mast cells exposed to $48 / 80$ or the ionophores A-23187 and X-537A. Proc. Natl. Acad. Sci. U. S. A., 71: 408 (1974).

4. Conover, J. H. Bonforte, R. J., Hathaway, P., Paciuc, S., Conod, E. J Hirshorn, K., and Kopel. F. B. Studies on ciliary dyskinesia factor in cystic fibrosis. I. Bioassay and heterozygote detection in serum. Pediat. Res., 7: $220(1973)$

5. di Sant Agnese, P. A.. Darling, R. C.. Perer, G. A.. and Shea, E.: Abnormal electrolyte composition of sweat in cystic fibrosis of the pancreas. Pediatrics, 12: 40) (1953).

6. di Sant Agnese, P. A., and Talamo, R. C.: Pathogenesis and physiopathology of cystic fibrosis of the pancreas: Fibrocystic disease of the pancreas (mucoviscidosis) N. Engl. J. Med., 277: 1287, 1343, 1399 (1969).

7. Eimerl, S., Savion, N.. Heichal, O., and Selinger, Z.: Induction of enzyme secretion in rat pancreatic slices using the ionophore A-23187 and calcium. J. Biol. Chem., 249: 3991 (1974)

8. Foreman, J. C.. Mongar, J. L.. and Gomperts, B. D.: Calcium-ionophores and movements of calcium ions following the physiological stimulus to a secretory process. Nature, 245: 249 (1973).

9. Guler, E., Pallavicine, C. J.. Swerdlow. H., and di Sant Agnese, P. A.: The role of calcium in submaxillary saliva of patients with cystic fibrosis. J. Pediat. $71: 585$ (1967)

10. Kagayama, M., and Douglas, W. W.: Flectron microscope evidence of calcium-induced exocytosis in mast cells treated with $48 / 80$ or the ionophores A-23187 and X-537A. J. Cell Biol., 62: 519 (1974).

11. Lobeck, C. C.: Cystic fibrosis of the pancreas. In: Metabolic Basis of Inherited Disease, 3rd ed. (McGraw-Hill, New York, pp. 1605, J. B. Stanbury, J. B. Wyngaarden, and D. S. Fredrickson: 1972).

12. Mangos, J. A., and MeSherry. N. R.: Sodium transport: Inhibitory factor in sweat of patients with cystic fibrosis. Science, 158: 135 (1967).

13. Mangos, J. A.. and McSherry, N. R.: Study on the mechanism of inhibition of sodium transport in cystic fibrosis of the pancreas. Pediat. Res.. 2: 387 $(1968)$.

14. Mangos, J. A., McSherry. N. R., and Benke, P. J.: A sodium transport inhibitory factor in the saliva of patients with cystic fibrosis of the pancreas Pediat. Res., l: 436 (1967).

15. Pressman, B. C.: Properties of ionophores with broad range cation selectivity. Fed. Proc.. 32: 1698 (1973)

16. Reed, P. W., and Lardy, H. A.: A23187: A divalent cation ionophore. J. Biol. Chem. 247: 6970) (1972).

17. Satir. P.: Ionophore-mediated calcium entry induces mussel gill ciliary arrest. Science, 190: $586(1975)$.

18. Setinger. Z., timerl, S.. and Schramm, M.: A calcium ionophore stimulating the action of epinephrine or the $\alpha$ adrenergic receptor. Proc. Natl. Acad Sci. U.S. A.. 7l: 128(1974).

19. Spock. A., Huck. H. M. C'. Cress, H., and Logan. W. S.: Abnormal serum factor in patients with cystic fibrosis of the pancreas. Pediat. Res., $1: 173$ (1967).

20. Williams, S. A., and Lee, M.: Pancreatic acinar cells: use of a ca ${ }^{+}+$ionophore to separate enzyme release from carly steps in stimulus-secretion coupling. Biochem. Biophys. Res. Commun., 60: 542 (1974).

21. Wong. 1). T., Wilkinson. J. R., Hamill, R. L., and Horng, J. S.: Effects of antibiestic ionophore A 23187 on oxidative phosphorylation and calcium transport of liver mitochondria. Arch. Biochem. Biophys., 156: 578 (1973)

22. Wotman, S., Mandel, I. I)., Mercadante, J., and Denning, C. R.: Parotid and and submaxillary ealcium in human cystic fibrosis. Arch. Oral Biol., /6: 663 (1971)

23. Dr. James $H$. Conover is the recipient of Cystic Fibrosis Foundation Research Scholar Award.

24. This work was supported by grants from the National Foundation-March of Dimes (1-392) and by the Cystic Fibrosis Foundation.

25. Requests for reprints should be addressed to: J. H. Conover, Ph.D., Department of Pediatrics, Albert Einstein (ollege of Medicine, 1300 Morris Park Ave., Bronx, N.Y. 10461 (USA).

26. Received for publication May 11.1976.

27. Accepted for publication August 12. 1976. 